\title{
Social Media and Health Care: Usage Pattern of Consumers and the Success Factors
}

\author{
Ambeesh Mon.S
}

\begin{abstract}
Nowadays, healthcare organizations such as clinics and hospitals have increasingly embarked on Social Media strategies, which involve establishing an organizational presence on the major social media platforms. SM is accepted as a means to evoke patients' knowledge on their health concerns which in turn trigger initiatives to search for healthcare products. This study is an exploration on the usage pattern of Social Media platforms for Healthcare Services by the patients or bystanders of at a tertiary level corporate health and wellness centre in Abudabi. Youth are actively searching for heath contents in social media and the information influence the significant aspects of consumer behavior. Search is more on specialty and medical terms so the content develops need to pay attention to these key aspects. Rather than health, the aspects related to wellness are getting more attention on social media plat forms. Conscious attempts while developing the content, encouraging review writing and commenting by professionals and consumers can be used to overcome the barriers regarding authenticity and quality of information.
\end{abstract}

Key words: Social media, Healthcare, Wellness, Usage pattern,

\section{INTRODUCTION}

Social media includes websites and applications that help people to generate and share content or to enable participation in social networks. All the popular social media sites like Facebook, Whatsapp, WeChat, QZone, Instagram and Twitter are extensively enjoyed by individuals across the world. Now business organizations also make use of social media to foster further growth by promoting their products among the existing and potential customers. This cost effective way of marketing results in increased brand awareness, high conversion rates and better customer satisfaction alongside other key conventional accomplishments that a marketer aims through promotion. Healthcare organizations such as clinics and hospitals have increasingly embarked on Social Media strategies, which involve establishing an organizational presence on the major social media platforms.

SM is accepted as a means to evoke patients' knowledge on their health concerns which in turn trigger initiatives to search for healthcare products. On SM, people advertise and communicate with themselves on a personal level, which has a very high positive impact on marketing of healthcare. Almost all healthcare providers capitalize on social media to get hold of their customers by providing product information, potential benefits, health education, promotion, branding and so on. The ever increasing competition in the

Revised Manuscript Received on October 25, 2019

* Correspondence Author

Dr.Ambeesh Mon.S, Assistant Professor, Institute of Management in Kerala University of Kerala, Thiruvanthapuram industry prompt heath care providers to adopt aggressive marketing strategies and social media serve as a prompt and crucial platform for them to unleash the plans. So, Social Media Marketing (SMM) and Social Media Content Marketing (SMCM) are going to be major tools for health care industry in the coming years. This study is an exploration on the usage pattern of Social Media platforms for Healthcare Services by the patients or bystanders of at a tertiary level corporate health and wellness centre in Abudabi.

\section{OBJECTIVES}

1. To examine usage pattern of Social Media platforms for Healthcare Services by consumers

2. To identify the factors that determines the success of Social Media Marketing of healthcare.

\section{RATIONALE}

All the four key characterizes of services such as intangibility, inseparability, perishability and variability have remarkable impact on health service industry. SM platforms that incorporate patient education with online peer-to-peer communication, using information sharing on aspects like conditions, symptoms and treatments to link patients together are getting widespread acceptance among people. Considering the changes in recent years such as the increased access to internet, the existence of affordable mobile devices and the ease of communication due to the growth of SM, it is worth exploring the impact of SM on healthcare services. The group covered in the study enjoys high level of disposable income and are more concerned on health and wellness. This category of consumers is more inclined to the use of social media for uses other than entertainment. They trust the credible contents in SM platforms and are influenced by the leads, reviews and electronic word of mouth.

\section{METHODOLOGY}

The study is exploratory in nature. Both secondary and primary data are used for the study. Search Engine Marketing Analytical Reports and SM Reports availed online are found to be useful to gain preliminary insights. Primary data is collected by interviewing the patients or bystanders a tertiary level corporate health and wellness centre in Abudabi using a structured questionnaire. The period of study is January, 2019. Random sampling is used for the study and the actual sample size is 108 against 150

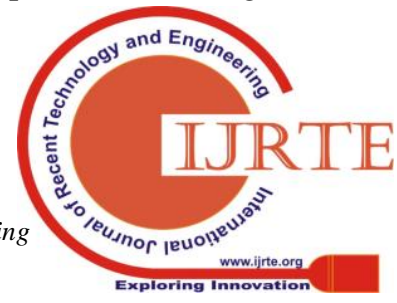


samples tried to avail. Descriptive statistics is used for analysis.

\section{REVIEW OF LITERATURE}

Nick Hajli (2014) says that online communities have significant influence on the online communication channels between healthcare service providers and consumers. This study conducted in Iran reaffirms that online health communities have rose to the level of reliable venues for heath information sharing. The study sheds light on consumer behavior in health care sector, especially on satisfaction.

Cecilia Backman et. al(2013) opinion that social media emerge as a prominent force because of its' informal communication style. This actually represents both possibility and liability for healthcare organizations. The opportunities include the arena for communicating with consumers with effectiveness and efficiency on all relevant aspects of service and the accomplishments of the firm that in turn boost the brand equity. Ensuring information accuracy and safeguarding security, of both the firm and consumer, are identified as the major challenges. They advocates for appropriate policies and training to developers and users to mitigate risk and tap the benefits of social media marketing. The increasing usage of social media for healthcare education and other philanthropic use is also mentioned by the researchers.

Katherine Chretien and Terry Kind (2013) opinionthat this is an exciting time to practice medicine at digital age. The vast opportunity extended by the use ogf social media in the communication of relevant aspects of healthcare is the real trigger to their excitement. The way social media change interactions and relationships through message amplification, quick exchange and engagement represent a veritable social revolution that healthcare service providers can tap. Patients not only find health information, but also engage in discussion forums and share their illness journeys. This is far beyond the common use of such platforms for appointment setting, prescription notification and result reporting.

Karl Vance et.al(2008) identifies the popular social media networks as a popular source of health information among teens and young adults. The work reiterates the advantages of this mode of communication characterized by low cost, rapid transmission and user interaction. They make a strong appeal to the healthcare providers to make meticulous use of this wonderful opportunity to converse with valuable customer base.

\section{DISCUSSION AND RESULTS}

Among the 108 respondents, $34.3 \%$ belong to the age group of $20-30$ years and $36.10 \%$ are in the age group of $31-40$ years. This indicates that youth are paying more attention to social media marketing on healthcare. About $51 \%$ of the respondents search for health content actively and purposefully. Specialty and medical terms are key aspects that the majority of users search for. It is followed $56 \%$ of respondents search by Medical terms, $51 \%$ search by Specialty, 23\% search by Facility, 20\% search by doctor and $19 \%$ search by location. The post that attracts the users of social media are related to wellness than health. The posts with contents regarding weight loss, nutrition, sleepless and cosmetics receive more views and responses.

Table I : The frequency of popular SM portal usage

\begin{tabular}{|c|l|l|l|l|l|}
\hline & Facebook & $\begin{array}{c}\text { Linked } \\
\text { In }\end{array}$ & Twitter & Instagram & YouTube \\
\hline Never & 5.6 & 0.9 & 2.8 & 7.4 & 0 \\
\hline Monthly & 1.9 & 8.3 & 1.9 & 3.7 & 1.9 \\
\hline Weekly & 4.6 & 9.3 & 6.5 & 2.8 & 10.2 \\
\hline Daily & 50.9 & 10.2 & 7.4 & 19.4 & 29.6 \\
\hline$>$ 1x/day & 8.3 & 0.9 & 2.8 & 4.6 & 8.3 \\
\hline Hourly & 14.8 & 0.9 & 1.9 & 7.4 & 1.9 \\
\hline Total & 86.1 & 30.6 & 23.1 & 45.4 & 51.9 \\
\hline Non-User & 13.9 & 69.4 & 76.9 & 54.6 & 48.1 \\
\hline
\end{tabular}

Daily users of SM platforms are more among the respondents. That usage frequency highest for Facebook (50.9\%), followed by youtube $(29.6 \%)$ and Instagram(19.4\%).

Table II:SM Portal usage pattern between male and female

\begin{tabular}{|c|c|c|c|c|c|c|c|}
\hline & Gender & $\mathbf{N}$ & Mean & $\begin{array}{c}\text { St. } \\
\text { Deviation }\end{array}$ & $\begin{array}{c}T \\
\text { Value }\end{array}$ & df & $\begin{array}{c}\text { P-Valu } \\
\text { e }\end{array}$ \\
\hline \multirow{2}{*}{$\begin{array}{l}\text { Face } \\
\text { book }\end{array}$} & Male & 33 & 3.88 & 1.219 & \multirow[t]{2}{*}{-1.601} & \multirow[t]{2}{*}{91} & \multirow[t]{2}{*}{0.486} \\
\hline & Female & 60 & 4.3 & 1.212 & & & \\
\hline \multirow{2}{*}{$\begin{array}{l}\text { Linked } \\
\text { In }\end{array}$} & Male & 12 & 2.83 & 1.115 & \multirow[t]{2}{*}{-1.313} & \multirow[t]{2}{*}{31} & \multirow[t]{2}{*}{0.87} \\
\hline & Female & 21 & 3.33 & 1.017 & & & \\
\hline \multirow{2}{*}{$\begin{array}{l}\text { Twitte } \\
\mathrm{r}\end{array}$} & Male & 11 & 2.91 & 1.221 & \multirow[t]{2}{*}{-1.923} & \multirow[t]{2}{*}{23} & \multirow[t]{2}{*}{0.787} \\
\hline & Female & 14 & 3.93 & 1.385 & & & \\
\hline \multirow{2}{*}{$\begin{array}{l}\text { Insta } \\
\text { gram }\end{array}$} & Male & 14 & 3 & 1.71 & \multirow[t]{2}{*}{-2.03} & \multirow[t]{2}{*}{47} & \multirow[t]{2}{*}{0.177} \\
\hline & Female & 35 & 4 & 1.495 & & & \\
\hline \multirow{2}{*}{$\begin{array}{l}\text { You } \\
\text { Tube }\end{array}$} & Male & 18 & 3.83 & 0.786 & \multirow[t]{2}{*}{$\begin{array}{c}-0.832 \\
\end{array}$} & \multirow[t]{2}{*}{54} & \\
\hline & Female & 38 & 4.03 & 0.822 & & & \\
\hline
\end{tabular}

It is relevant to notice that the usage pattern of different social media for availing heath care information do not differ significantly among men and women.

The portal usage pattern across the different age groups is analyzed using ANOVA and the results are summarized below.

Table III- Distribution of SM Portal usage pattern b/n Age group

\begin{tabular}{|c|c|c|c|c|c|c|c|}
\hline & $\begin{array}{c}\text { Age } \\
\text { Group }\end{array}$ & N & Mean & $\begin{array}{c}\text { St. } \\
\text { Deviation }\end{array}$ & $\begin{array}{c}\text { F - } \\
\text { Value }\end{array}$ & df & Sig. \\
\hline Face & $0-12$ & 0 & $\cdot$ & $\cdot$ & 1.176 & 4 & 0.32 \\
book & $13-19$ & 2 & 4 & 0 & & $\&$ & 7 \\
\cline { 2 - 5 } &
\end{tabular}




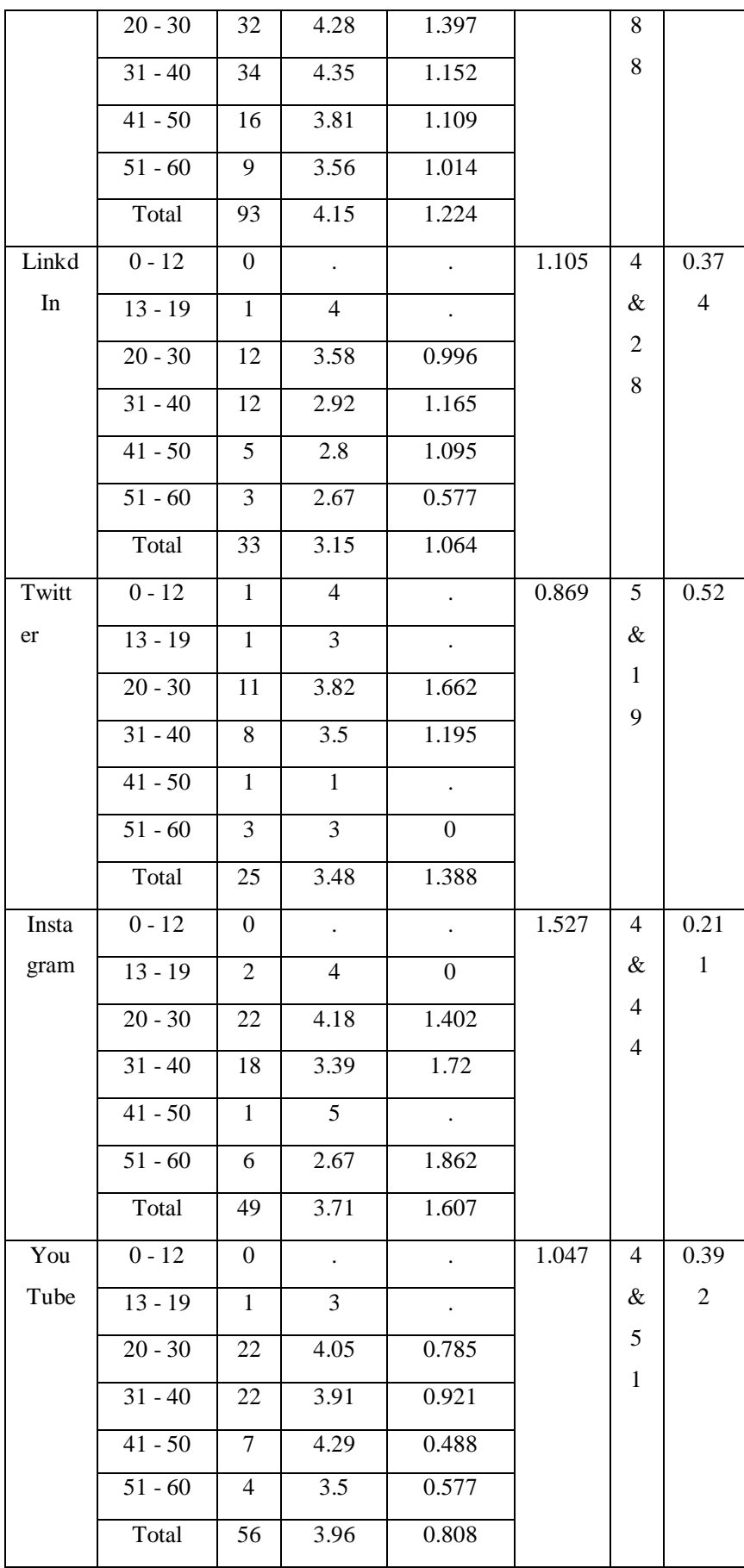

NS: The difference is not significant.

Here the p-value shows that the age wise SM portal usage do not differ significantly among the various platforms.

\section{IMPLICATIONS AND CONCLUSION}

Social media marketing enjoys a significant role in modern day business. The increased access to internet, availability of affordable mobile devices and the ease of communication trigger the use of Social media. The possibilities to unleash the vast potential of social media in the marketing of health and wellness products are unveiled in the study. Youth are actively searching for heath contents in social media and the information influence the significant aspects of consumer behavior. Search is more on specialty and medical terms so the content develops need to pay attention to these key aspects. Rather than health, the aspects related to wellness are getting more attention on social media plat forms. This may be due to the concerns regarding quality and authenticity of information that are crucial in case of heath care. In other words, the authenticity of electronic word of mouth is a major concern in case of social media marketing of health care products. Conscious attempts while developing the content, encouraging review writing and commenting by professionals and consumers can be used to overcome the

\section{REFERENCES}

[1]. [Online web]Katherine C. Chretien and Twerry Kid, Social Media and Clinical care, https://doi.org/10.1161/CIRCULATIONAHA.112.128017

[2]. Amy L Kotsenas, Makala Arce, Lee Aase (2016), "The strategic imperative for the use of social media in healthcar", Journaal of Americaan College of Radiology, 15(1), 155-161

[3]. Karl Vance, Robert P. Dallavale (2009), "Social internet sites as a source of public health information", Dermatologic clinics, Volume27, Issue2,p133-136

[4]. Nick Hajli (2014),'Developing Online health communities through digital media", International Journal of Information Management, Volume 34, Issue 2, p311-314

[5]. Walter Wymer(2010), "Rethinking the boundaries of social marketing: Activism or advertising”, Journal of Business Research63(2),99-103.

\section{AUTHORS PROFILE}

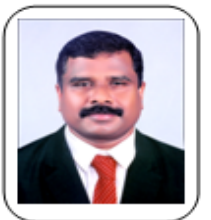

Dr. Ambeesh Mon.S is a Post Graduate in Business Administration with specialization in Operations and Marketing Management. $\mathrm{He}$ holds $\mathrm{PhD}$ in the Faculty Management from the University of Kerala.He enjoys 19 years of experience in teaching and research with Management Information Systems, Supply Chain Management and Quality as the thrust areas. Among the 21 articles published in leading journals, majority focus on socially relevant aspects like alcoholism, healthcare and sustainable development. Apart from this he enjoys training and public speaking.Email :Ambeeshs@gamil.com 